\title{
BADAN PENYELESAIAN SENGKETA KONSUMEN SEBAGAI PERWUJUDAN PERLINDUNGAN HAK KONSUMEN
}

\author{
Murni dan Sri Maharani MTVM \\ Universitas Trunojoyo Madura \\ Raya Telang PO Box 2, Bangkalan, Madura \\ Email:murni_msy@yahoo.co.id
}

\begin{abstract}
The background of this study is the absence of the Consumer Dispute Resolution Board (BPSK) in the region of Madura. This legal empirical study, in order to examine the legal aspects as well as to identify opportunities and obstacles to the establishment of BPSK. The results of this study put the structural problem as the main reason, unrealized funding that are being considered by the government. Important to be done is to provide a basis for the establishment of BPSK through regulation in each area and the government's commitment to provide the financial support in the budget.
\end{abstract}

Key words: alternative, model, dispute, consumer

\begin{abstract}
Abstrak
Penelitian ini dilatar belakangi belum adanya Badan Penyelesaian Sengketa Konsumen (BPSK) di wilayah Madura. Ini adalah penelitian hukum empiris, tujuannya untuk mengkaji aspek hukum dan mengetahui peluang juga kelemahan pendirian kelembagaan BPSK di wilayah Madura. Hasil dari penelitian ini menempatkan problem struktural menjadi alasan terdepan tidak terbentuknya BPSK di wilayah Madura, alasan pendanaan juga menjadi pertimbangan pemerintah daerah tidak merealisasikan lembaga ini. Penting untuk dilakukan adalah memberikan payung hukum bagi lahirnya kelembagaan BPSK melalui Peraturan Daerah di masing-masing Kabupaten dan komitmen pemerintah untuk memberikan dukungan financial dalam APBD.
\end{abstract}

Kata kunci: alternatif, model, sengketa, konsumen

\section{Latar Belakang}

Meningkatnya laju perekonomian Kabupaten Bangkalan, sebagai pintu gerbang di berbagai daerah, berdampak pada pertama menjadi barometerjuga menunjukkan peningkatan konsumsi masyarakat terhadap adanya perkembangan konsumsi masyarakat berbagai macam barang maupun jasa, Bangkalan serta kota-kota di Pulau Madura tidak terkecuali wilayah Madura yang kini lainnya mengikuti kota besar Surabaya. Akses telah terhubung oleh Jembatan Suramadu. Jembatan Suramadu telah mempermudah Pasca operasionalisasi jembatan Suramadu, pergerakan barang menuju Pulau Madura. 
Produk kecantikan dilengkapi dengan rumah cantik/klinik estetika, produk makanan dan minuman, jasa KBIH, usaha perumahan, bahkanproduk-produkelektronikyangcanggih serta automotif telah berkembang sangat pesat demikian pula produk khas Madura oleholeh khas Madura, wisata kuliner, batik khas Madura telah beredar di Surabaya,. Namun, berhubung pengetahuan konsumen terhadap rangkaian proses produksi maupun realisasi pelayanan jasa sangat rendah menyebabkan konsumen rentan terhadap kecurangankecurangan yang mungkin dilakukan oleh pelaku usaha. Banyak sekali keluhan-keluhan pada masyarakat selaku konsumen di Madura yang tidak tahu bagaimana mempertahankan haknya ketika mereka berhadapan dengan pelaku usaha nakal, seperti ikan berformalin, pengembang perumahan nakal di Bangkalan, korban penggunaan kosmetik $^{1}$ serta penyedia jasa ibadah haji KBIH yang ada di Pamekasan. ${ }^{2}$

Berdasarkan penelusuran tim peneliti terkait kasus konsumen, di empat kabupaten di wilayah Madura mempunyai karakter yang sama. Kasus-kasus yang bersumber dari pelaku usaha swasta atau produsen swasta yaitu korban konsumen perumahan/property dengan modus rumah tidak sesuai spesifikasi dan tidak adanya fasilitas umum, produk makanan minuman kadaluarsa, pelayanan wisata religi atau umroh tidak sesuai promo dan ditimbunnya gas/LPG oleh distributor. ${ }^{3}$

Kepentingan pelaku usaha dan kepentingan konsumen yang saling berhadapan menuntut pemerintah untuk menyediakan sarana hukum bagi masyarakat dalam menyelesaikan sengketa yang terjadi antara dua pihak yaitu konsumen dan produsen, melalui dua mekanisme yaitu melalui jalur litigasi (formal peradilan) dan jalur non litigasi melalui Badan Penyelesaian Sengketa Konsumen (BPSK). Mekanisme di luar pengadilan rupanya lebih dipilih karena bersifat cepat, sederhana dan jauh dari komersialisasi jabatan layaknya sistem formal karena strukturnya tidak hanya melibatkan masyarakat sebagai end user atau konsumen akhir, tetapi juga terdapat pemerintah dan pelaku usaha.

Sebagai amanat dari tujuan perekonomian nasional yang telah ditetapkan dalam UUD 1945, yakni untuk mewujudkan kesejahteraan kepada masyarakat inilah Badan Penyelesaian Sengketa Konsumen diberikan peran dengan kewenangan luas sebagai pengawas dalam sistem perekonomian yang sehat dan bertanggungjawab, terutama sebagai pilar dalam perlindungan hukum terhadap konsumen melalui Undang-Undang Nomor 8 Tahun 1999 Tentang Perlindungan Konsumen. Payung hukum dimaksudkan untuk menciptakan iklim usaha yang sehat dalam rangka penyediaan barang dan atau jasa

1 Keterangan Bapak Jimhur Saros, YLKI Madura dan Laporan masyarakat pada UPKH, Fakultas Hukum Universitas Trunojoyo Madura, 2012-2013.

2 Koran Madura, Kemenag Belum Mampu Mendeteksi, http://www.koranmadura.com/kemenag-belummampu-mendeteksi/, diakses 9 Maret 2013 pukul 20.00 WIB.

3 Hasil penelusuran tim peneliti terkait karakteristik kasus konsumen di wilayah Madura periode Mei-Juli 2013. 
yang berkualitas.

Namun untuk mewujudkan amanat undang-undnag dalam membentuk BPSK oleh setiap daerah Kabupaten ternyata tidak mudah masih terdapat beberapa kendala, baik kendala dari sisi kelembagaannya, teknis maupun struktural. Sehingga ketiadaan BPSK dan minimnya pengetahuan hak-hak konsumen oleh masyarakat di Madura menyebabkan banyaknya keluhan-keluhan konsumen tersebut hanya menjadi cerita belaka, stigma negatif bila berhadapan dengan hukum formal dan rendahnya kepercayaan terhadap sistem peradilan akhirnya menyurutkan langkah mereka untuk mempertahankan hak-haknya sebagai konsumen.

Kesulitan akan semakin menjadi tatkala ada keluhan dari konsumen-konsumen sebagai turis domestik di Madura yang membeli produk lokal maupun produk luar ketika berada di Madura, mereka tidak tahu harus menyampaikan kemana. Dengan demikian keberadaan BPSK dapat menjadi solusi bagi konsumen untuk memperjuangkan hak-haknya serta dapat menyurutkan niat pelaku usaha lokal yang nakal dan secara tidak langsung akan meningkatkan citra Madura di hadapan masyarakat maupun para pendatang di Pulau Madura.

Tujuan pembangunan nasional Indonesia adalah mewujudkan masyarakat adil dan makmur yang merata dalam era demokrasi ekonomi berdasarkan Pancasila dan UndangUndang Dasar Negara Republik Indonesia Tahun 1945. Pembangunan perekonomian nasional pada era globalisasi harus dapat mendukung tumbuhnya dunia usaha sehingga mampu menghasilkan bermacam-macam barang dan/atau jasa yang dapat meningkatkan kesejahteraan masyarakat banyak, sekaligus mendapatkan kepastian atas barang dan atau jasa yang diperoleh dari perdagangan tanpa mengakibatkan kerugian kepada konsumen.

Permasalahan yang timbul dalam situasi ini adalah:

"Lemahnya perlindungan hukum terhadap konsumen di Madura yang ingin mempertahankanhak-haknya",olehkarenanya untuk mendekatkan pada tercapainya keadilan konsumen untuk mendapatkan barang yang murah dan berkualitas, maka sebagai pemenuhan hak konsumen tersebut dapat dilakukan melalui pendirian BPSK disetiap Kabupaten di Madura. Untuk itu dalam penelitian ini menjawab beberapa hal yang menjadi dasar bagi analisis pendirian BPSK di wilayah Madura, antara lain:

1. Dalam rangka mewujudkan hak-hak konsumen di Madura, Bagaimanakah kebijakan Pemerintah Daerah terkait pendirian BPSK konsumen di wilayah Madura pasca disahkan UndangUndang Nomor 8 Tahun 1999 tentang Perlindungan Konsumen?

2. Bagaimanakah model pengaturan hukum bagi pembentukan BPSK di wilayah Madura?

Penelitian ini merupakan penelitian hukum empiris atau penelitian hukum non doktrinal disebut juga sebagai penelitian 
hukum sosiologis (sosio legal research) yang dalam penelitian ini menitikberatkan terhadap bekerjanya hukum dimasyarakat. ${ }^{4}$

Lokasi penelitian dilaksanakan pada empat Kabupaten di Pulau Madura yaitu: Kabupaten Bangkalan, Kabupaten Sampang, Kabupaten Pamekasa, Kabupaten Sumenep, serta kegiatan analisis di laboratorium Hukum Universitas Trunojoyo.

Data primer diperoleh dengan mengunakan Teknik wawancara mendalam melalui FGD (Focus Group Discussion) dengan berbagai pihak, instansi terkait serta masyarakat.. Informan kunci yang menjadi sumber data primer dalam penelitian ini adalah yang berkaitan langsung sebagai pihak-pihak yang terlibat dalam rencana pelembagaan BPSK di Madura, antara lain: Masyarakat/Konsumen, Pelaku Usaha, dan Unsur Pemerintahan Daerah terkait penelitian. Sumber data sekunder diperoleh dari kantorkantor pemerintahan maupun pelaku usaha dan juga kantor-kantor penegak hukum bila diperlukan.

Data kualitatif yang diperoleh selama penelitian tersebut, kemudian ditambah dengan pernyataan-pernyataan para informan (interpretasi emik) dijadikan sebagai dasar untuk menyusun deskripsi menurut persepsi peneliti (interpretasi etik) yang menyangkut berbagai hal guna mendukung proses konstruksi yuridis BPSK di Madura.

\section{Pembahasan}

A. Kebijakan Pemerintah Daerah Terkait Pembentukan BPSK di Madura Pasca Undang-undang Nomor 8 Tahun 1999 Tentang Perlindungan Konsumen

Sejak di undangkan UUPK pada tahun 1999 dan ini kini telah berusia 15 (lima belas) tahun, kenyatannya di Madura belum terbentuk lembaga yang mengarah pada perlindungan konsumen yang melibatkan campur tangan pemerintah.

Usaha-usaha yang dilakukan oleh pemerintah di empat Kabupaten di Madura hampir semuanya sama yaitu masih bersifat lintas sektoral. Penelusuran kami pada Dinas Perindustrian dan Perdagangan setiap tahun mereka mempunyai program sosialisasi dengan tema "Perlindungan Konsumen".

Di Kabupaten Sumenep Disperindag memprogramkan setiap minggu melakukan operasi pasar terpadu bersama dinas kesehatan. Disperindag menkhususkan lebih pada otoritas tata niaga pasar, sedangkan dinkes terkait ijin layak edar. Beberapa tahun ini disperindag sebagai SKPD yang mempunyai sie khusus perlindungan konsumen telah mengusulkan berdirinya BPSK di wilayahnya, akan tetapi hal ini tidak pernah menjadi skala prioritas program legislasi daerah, dengan alasan pendanaan yang bersumber dari APBD. ${ }^{5}$

4 Bambang Sunggono, Pengantar Metode Penelitian Hukum, Rajawali, Jakarta, 2006, hlm. 34.

5 Wawancara dengan Bapak Didik Prayitno, Bidang Promosi dan Perlindungan Konsumen Disperindag PemKab. Sumenep, 1 Agustus 2013. 
Perhatian terhadap perlindungan konsumen di Kabupaten Pamekasan sebenarnya lebih berkembang di banding Kabupaten lain di Madura, tercatat ada 3 (tiga) LPKSM (Lembaga Perlindungan Konsumen Swadaya Masyarakat) yaitu PKPU, LPPKI, dan LPKNI. ${ }^{6}$ Dalam Peratutan Pemerintah (PP) Nomor 59 Tahun 2001 (59/2001) Tentang Lembaga perlindungan Konsumen Swadaya Masyarakat pada pasal 1 ayat 3 di tentukan bahwa Lembaga Perlindungan Konsumen Swadaya Masyarakat yang selanjutnya disebut LPKSM adalah Lembaga Non Pemerintah yang terdaftar dan diakui oleh Pemerintah yang mempunyai kegiatan menangani perlindungan konsumen. Sedangkan di Pasal 3 dalam PP ini mengatur tugas LPKSM yaitu meliputi kegiatan:

a. menyebarkan informasi dalam rangka meningkatkan kesadaran atas hak dan kewajiban serta kehati-hatian konsumen, dalam mengkonsumsi barang dan/atau jasa;

b. memberikan nasihat kepada konsumen yang memerlukan;

c. melakukan kerja sama dengan instansi terkait dalam upaya mewujudkan perlindungan konsumen;

d. membantu konsumen dalam memperjuangkan haknya, termasuk menerima keluhan atau pengaduan konsumen; e. melakukan pengawasan bersama pemerintah dan masyarakat terhadap pelaksanaan perlindungankonsumen.

Setidaknya dengan adanya tiga LPKSM di Kabupaten Pamekasan telah memberikan rasa nyaman sebagai konsumen untuk menikmati berbagai kebutuhan fisik masyarakat. Dengan memperhatikan tugas-tugas yang di emban oleh LPKSM ini. Setiap ada kegiatan terkait operasi pasar yang bertujuan untuk pengawasan peredaran makanan minuman di Kabupaten Pamekasan ketiga LPKSM ini di libatkan, hal ini di kuatkan dengan Surat Keputusan (SK) Bupati Pamekasan nomor 188/141.131/2013 tentang Pembentukan Tim Koordinasi Pembinaan dan Pengawasan Peredaran Mamin Konsumsi Masyarakat. Meskipun hanya berkisar pada pengawasan mamin, paling tidak sudah ada perhatian oleh pemerintah terhadap konsumen.

Selebihnya di Kabupaten lain masih pada standart sosialisasi baik secara langsung melalui penyuluhan, maupun penerbitan brosur "menjadi konsumen cerdas" dan operasi pasar yang dilakukan bekerjasama dengan Dinas Kesehatan.

Penyebab lain tidak optimalnya program operasi pasar di karenakan minimnya PPNS (Penyidik Pegawai Negeri Sipil) yang di punyai oleh Disperindag menyebabkan tidak berjalannya penegakan hukum di bidang perlindungan konsumen ini, karena hanya

6 Wawancara dengan Bapak Hendradi Kabid, Perlindungan Konsumen dan Bapak Imam Hidajad PPNS Disperindag Kabupaten Pamekasan, 25 Juli 2013. 
PPNS yang berwenang mengambil tindakan akibat pelanggaran-pelanggaran yang dilakukan oleh pelaku usaha. Selain itu alasan kemanusiaan bagi pelaku usaha kecil apabila mereka di tindak.

Program-program pemerintah tersebut senyatanya menjadi tidak maksimal karena hanya untuk melakukan kewajiban kerja dan bersifat preventif saja, sedangkan terbentuknya BPSK tidak menjadi prioritas bagi pemerintahan di daerah padahal ini diamanatkan oleh pasal 49 UUPK. Alasan yang dikemukaan tidak ada payung hukum yang merupakan produk legislasi di daerah bagi pendiriannya dan keberadaannya menjadi beban bagi APBD masing-masing daerah.

\section{B. Rumusan Model Pengaturan Hukum BPSK sebagai Perwujudan Perlindungan terhadap Konsumen di Wilayah Madura}

Perlindungan hukum adalah suatu perlindungan yang diberikan kepada subyek hukum ke dalam bentuk perangkat baik yang bersifat preventif maupun yang bersifat represif, baik yang lisan maupun yang tertulis. Dengan kata lain dapat dikatakan bahwa perlindungan hukum sebagai suatu gambaran tersendiri dari fungsi hukum itu sendiri, yang memiliki konsep bahwa hukum memberikan suatu keadilan, ketertiban, kepastian, kemanfaatan dan kedamaian. Pengertian di atas mengundang beberapa ahli untuk mengungkapkan pendapatnya mengenai pengertian dari perlindungan hukum diantaranya: a. Menurut Satjipto Raharjo mendefinisikan Perlindungan Hukum adalah memberikan pengayoman kepada hak asasi manusia yang dirugikan orang lain dan perlindungan tersebut diberikan kepada masyarakat agar mereka dapat menikmati semua hak-hak yang diberikan oleh hukum.

b. Menurut Philipus M. Hadjon membagi perlindungan hukum kedalam dua bagian yaitu

c. Perlindungan hukum represif yaitu dengan cara menerapkan sanksi terhadap pelaku agar dapat memulihkan hukum pada keadaan sebenarnya. Perlindungan jenis ini biasanya dilakukan di pengadilan

- Perlindungan hukum Preventif yaitu perlindungan hukum yang bertujuan untuk mencegah terjadinya sengketa Perlindungan hukum jenis ini misalnya sebelum pemerintah menetapkan suatu aturan/keputusan rakyat dapat mengajukan keberatan atau diminta pendapatnya mengenai keputusan tersebut.

- Menurut CST Kansil Perlindungan Hukum adalah berbagai upaya hukum yang harus diberikan oleh aparat penegak hukum untuk memberikan rasa aman, baik secara pikiran maupun fisik dari gangguan dan berbagai ancaman dari pihak manapun.

d. Menurut Muktie, A. Fadjar Perlindungan Hukum adalah penyempitan arti dari perlindungan, dalam hal ini hanya 
perlindungan oleh hukum saja. Perlindungan yang diberikan oleh hukum, terkait pula dengan adanya hak dan kewajiban, dalam hal ini yang dimiliki oleh manusia sebagai subyek hukum dalam interaksinya dengan sesama manusia serta lingkungannya. Sebagai subyek hukum manusia memiliki hak dan kewajiban untuk melakukan suatu tindakan hukum. ${ }^{7}$

Pengaturan tentang perlindungan konsumen di Indonesia telah dimulai sejak zaman Hindia Belanda, kendatipun sebagian besar peraturan-peraturan tersebut pada saat ini sudah tidak berlaku lagi. Beberapa peraturan yang berkaitan dengan perlindungan konsumen pada saat itu antara lain:

1. Reglement Industriele Eigendom, $\mathrm{S}$, 1912-545, jo. S. 1913 No.

2. Hinder Ordonnantie (Ordonansi Gangguan), S. 1926-226 jo. S. 1927 449, jo. S. 1940-14 dan 450.

\section{Loodwit Ordonnantie (Ordonansi}

Timbal Karbonat), S. 1931 No. 28.

4. Tin Ordonnantie (Ordonansi Timah Putih), S. 1931-509.

5. Vuurwerk Ordonnantie (Ordonansi Petasan), S. 1932-143.

6. Verpakkings Ordonnantie (Ordonansi Kemasan), S. 1935 No. 161.

7. Ordonnantie $O p$ de Slacth Belasting (Ordonansi Pajak Sembelih), S. 1936671.
8. Sterkwerkannde Geneesmiddelen Ordonnantie (Ordonansi Obat Keras), S. 1937-641.

9. Bedrijfsrelementerings Ordonnantie (Ordonansi Penyaluran Perusahaan), S. $1938-86 .^{8}$

Pada sisi lain, dalam beberapa kitab undang-undang juga terdapat beberapa ketentuan yang dapat digunakan untuk melindungi konsumen, yaitu:

1. KUH Perdata: Bagian 2, Bab V, Buku II mengatur tentang kewajiban penjual dalam perjanjian jual beli.

2. KUHD: tentang pihak ketiga yang harus dilindungi, tentang perlindungan penumpang/barang muatan pada hukum maritim, ketentuan mengenai perantara, asuransi, surat berharga, kepalitian, dan sebagainya.

3. KUH Pidana: tentang pemalsuan, penipuan, pemalsuan merk, persaingan curang, dan sebagainya. ${ }^{9}$

Peranan konsumen, produsen dan pemerintah dalam mewujudkan perlindungan konsumen, merekomendasikan Dalam upaya mewujudkan perlindungan konsumen sangat tergantung pada peran dan sikap kritis konsumen sebagai pembeli barang atau jasa. Namun, faktor lain yang juga tidak kalah penting adalah sikap produsen sebagai pihak pemroduksi barang atau jasa yang seharusnya berorientasi pada kepuasan konsumen dan

7 Tesis Hukum, Pengertian, Perlindungan Hukum Menuru Para Ahli, http://tesishukum.com/pengertianperlindungan-hukum-menurut-para-ahli/, diakses 28 Agustus 2014 pukul 19.00 WIB.

8 Zulham, Hukum Perlindungan Konsumen, Kencana Prenada Media Group, Jakarta, 2013, hlm. 32.

9 Ibid., hlm. 33. 
barang yang diproduksi memenuhi standar mutu yang telah ditetapkan. Pemerintah dalam hal ini berkaitan dengan pembuatan UndangUndang Perlindungan Konsumen, dan Departemen Perdagangan harus mengawasi produk atau jasa yang beredar di dalam perdagangan dalam negeri, yang diekspor maupun yang diimpor, serta peran dari aktivitas organisasi konsumen itu sendiri. ${ }^{10}$

Dirumuskan Tujuan Negara RI dalam Pembukaan UUD Negara RI Tahun 1945, Alinea ke IV:

"Kemudian dari pada itu untuk membentuk suatu Pemerintah Negara Indonesia yang melindungi segenap bangsa Indonesia dan seluruh tumpah darah Indonesia dan untuk memajukan kesejahteraan umum, mencerdaskan kehidupan bangsa, dan ikut melaksanakan ketertiban dunia yang berdasarkan kemerdekaan, perdamaian abadi dan keadilan sosial".

Keadilan dapat dimaknai sebagai legalitas. Adalah adil jika suatu aturan diterapkan pada semua kasus di mana menurut isinya memang aturan tersebut harus diaplikasikan. Adalah tidak adil jika suatu aturan diterapkan pada satu kasus tetapi tidak pada kasus lain yang sama. Keadilan dalam arti legalitas adalah suatu kualitas yang tidak berhubungan dengan isi tataran aturan positif, tetapi dengan pelaksanaannya. Menurut legalitas, pernyataan bahwa tindakan individu adil atau tidak adli berarti legal atau illegal, yaitu tindakan tersebut sesuai atau tidak dengan norma hukum yang valid untuk menilai sebagai bagian dari tata hukum positif. ${ }^{11}$

Perlindungan konsumen merupakan masalah nasional sebab pada dasarnya semua orang adalah konsumen, melindungi konsumen adalah melindungi semua orang. Persoalan perlindungan hukum kepada konsumen adalah masalah hukum nasional, oleh karena itu perlindungan terhadap konsumen bertujuan untuk menjamin keselamatan, kemananan, dan kesehatan warga negara, sebagai tujuan negara.

Pasal 28 D butir (1) UUD RI Tahun 1945 mengatur: setiap orang berhak atas pengakuan, jaminan, perlindungan dan kepastian hukum yang adil serta perlakuan yang sama dihadapan hukum". Pasal 28 I, butir (4): "Perlindungan, pemajuan, penegakan dan pemenuhan hak asasi manusia adalah tanggung jawab Negara terutama pemerintah".

Perlindungan konsumen menjadi penting karena selama ini kedudukan konsumen pada umumnya lemah di hadapan pelaku usaha, merupakan kewajiban Negara melindungi hak-hak konsumen, sebagai bentuk pengakuan terhadap Hak Asasi Manusia, oleh karenanya akan dirumuskan berdirinya BPSK di wilayah Madura, sebagaimana analisa yuridis di bawah ini.

10 Euis Soliha, Peranan Konsumen, Produsen dan Pemerintah dalam Mewujudkan Perlindungan Konsumen, Jurnal Gema Stikubank, Volume 31 No. 5, Sekolah Tinggi Ilmu Ekonomi Stikubank, Semarang, 1999, hlm. 93-105.

11 Jimly Asshiddiqie \& M.Ali Safa'at, Teori Hans Kelsen Tentang Hukum, Konstitusi Press, Jakarta, 2012, hlm. 21. 
Undang-Undang Nomor 8 Tahun 1999 tentang Perlindungan Konsumen merupakan produk hukum yang bersifat peraturan payung" mengatur penyelesaian sengketa konsumen. Penyelesaian sengketa konsumen dilakukan dengan 2 jalan Penyelesaian Sengketa Konsumen hanya dari aspek perdata atau pertanggungjawaban perdata dengan cara melalui mediasi atau konsiliasi atau arbitrasi. Pada dasarnya upaya penyelesaian sengketa konsumen bersifat sukarela artinya pelaku usaha yang menolak atau tidak memberikan tanggapan atau bahkan tidak memenuhi gantirugi maka dapat memberikan kesempatan kepada konsumen untuk mengajukan gugatan kepada Badan Penyelesaian Sengketa Konsumen atau mengajukan ke pengadilan umum. Tuntutan ganti-rugi dan atau tuntutan pidana dapat dilakukan oleh konsumen yang dirugikan atau ahli warisnya dilakukan melalui gugatan perwakilan atau oleh lembaga swadaya masyarakat/hak gugat LSM. ${ }^{12}$

Dengan dasar filosofi bahwa konsumen tidak mengetahui secara pasti rangkaian proses produksi suatu produk yang menyebabkan konsumen rentan terhadap berbagai bentuk kecurangan yang mungkin dilakukan oleh pelaku usaha, menjadi acuan perlu adanya perlindungan pada konsumen. Perlindungan konsumen yang dimaksud secara khusus diatur dalam UU No. 8 Tahun 1999 tentang Perlindungan Konsumen, dimana dalam undang-undang tersebut ditentukan juga mengenai lembaga yang bertugas menyelesaikan sengketa konsumen yang timbul dari suatu transaksi konsumen. Salah satu lembaga yang dimaksud adalah Badan Penyelesaian Sengketa Konsumen (BPSK). BPSK sebagai salah satu lembaga penyelesaian sengketa mempunyai karakteristik khusus karena mempunyai sifat multifungsi, selain sebagai adjudication juga sekaligus sebagai consultative function. Penyelesaian melalui lembaga ini merupakan alternatif yang dapat ditempuh konsumen secara sukarela untuk memperjuangkan pemenuhan hak konsumen selain melalui peradilan umum. ${ }^{13}$

Wawancara mendalam dengan narasumber dari instansi teknis terkait perlindungan konsumen di wilayah Madura dan hasil analisis yuridis dalam penelitian ini, dapat di tegaskan bahwa untuk menentukan model pengaturan hukum bagi pendirian BPSK di Madura ini ada dua pendapat hukum yang bisa dipertimbangkan:

1. Tidak bisa di bentuk BPSK, karena tidak ada Peraturan Daerah yang mengaturnya.

2. Membentuk BPSK berdasarkan amanat pasal 49 UUPK tanpa Peraturan Daerah. ${ }^{14}$

Kedua pendapat tersebut sama-sama bisa di terima alasan pendukungnya, dengan analisis yuridis sebagaimana berikut ini:

12 Ari Purwadi, Model Penyelesaian Sengketa Konsumen di Indonesia, Jurnal Yustika, Volume 4 No. 2 , Desember 2001, Media Hukum dan Keadilan, 2001, hlm. 254-273.

13 Bernadetta T.Wulandari, Badan Penyelesaian Sengketa Konsumen (BPSK) Sebagai Alternatif Upaya Penegakan Hak Konsumen di Indonesia, Gloria Juris, Volume 6 No. 2, Oktober 2006, hlm. 142-151.

14 Hasil FGD dengan instansi terkait perlindungan konsumen di wilayah Madura, sepanjang 2013-2014. 
1. Pertama, tidak adanya peraturan daerah menyebabkan tidak berdirinya BPSK di Madura.

Pihak instansi teknis terkait sebagai representative dari pemerintah menyatakan bahwa untuk bisa mendirikan BPSK di wilayah Madura harus terlebih dahulu di bentuk Peraturan Daerahnya.

Pendapat ini bisa kita cermati melalui argumentasi hukum berikut: bahwasanya sebuah "Badan" baru dalam sistem penyelenggaraan pemerintahan di daerah harus diperhatikan pengaturan yang mengacu pada Undang-undang nomor 23 tahun 2014 tentang Pemerintahan Daerah (Selanjutnya di singkat UU 23/2014), Pasal 208 mengatur:

(1) Kepala daerah dan DPRD dalam menyelenggarakan Urusan

Pemerintahan dibantu oleh Perangkat Daerah.

(2) Perangkat Daerah sebagaimana dimaksud pada ayat (1) diisi oleh pegawai aparatur sipil negara.

Selanjutnya dalam Pasal 209 Ayat (2) UU 23/2014, di atur bahwa: Perangkat Daerah kabupaten/kota terdiri atas:
a. sekretariat daerah;
b. sekretariat DPRD;
c. inspektorat;
d. dinas;
e. badan; dan
f. Kecamatan.

Pembentukan dan Susunan Perangkat Daerah dalam Pasal 212 UU 23/2014 juga diatur sebagai berikut:

(1) Pembentukan dan susunan Perangkat Daerah sebagaimana dimaksud dalam Pasal 209 ayat (1) dan ayat (2) ditetapkan dengan Perda.

(2) Perda sebagaimana dimaksud pada ayat (1) berlaku setelah mendapat persetujuan dari Menteri bagi Perangkat Daerah provinsi dan dari gubernur sebagai wakil Pemerintah Pusat bagi Perangkat Daerah kabupaten/kota.

(3) Persetujuan Menteri atau gubernur sebagai wakil Pemerintah Pusat sebagaimana dimaksud pada ayat (2) diberikan berdasarkan pemetaan Urusan Pemerintahan Wajib yang tidak berkaitan dengan Pelayanan Dasar dan Urusan Pemerintahan Pilihan sebagaimana dimaksud dalam Pasal 24.

(4) Kedudukan, susunan organisasi, perincian tugas dan fungsi, serta tata kerja Perangkat Daerah sebagaimana dimaksud pada ayat (1) ditetapkan dengan Perkada. Memperhatikan Pasal 209 jo. Pasal 212 UU 23/2014 maka "Badan" sebagai salah satu unsur perangkat daerah, pembentukannya harus di dahului dengan diaturnya pendirian "badan" dimaksud dengan sebuah "Peraturan Daerah". Dengan demikian BPSK di wilayah Madura sesuai amanat pasal49 UUPK barubisa di bentuk bila masing-masing pemerintahan daerah terlebih dahulu mengaturnya dalam sebuah "Peraturan Daerah" tentang BPSK.

2. Kedua, Membentuk BPSK berdasarkan 
amanat pasal 49 UUPK tanpa Perda.

Pendapat kedua terkait pengaturan hukum pendirian BPSK di Madura memberikan argumentasi terbalik dengan pendapat pertama tetapi dengan mengacu pada pasal-pasal yang sama dalam UndangUndang pemerintahan Daerah.

Kalau kita perhatikan dalam pasal 49 UUPK yang mengatur:

1. Pemerintah membentuk badan penyelesaian sengketa konsumen di Daerah Tingkat II untuk menyelesaikan sengketa konsumen di luar pengadilan.

2. Untuk dapat diangkat menjadi anggota badan penyelesaian sengketa konsumen, seseorang harus memenuhi syarat sebagai berikut:
a. warga negara Republik Indonesia;
b. berbadan sehat;
c. berkelakuan baik;
d. tidak pernah dihukum karena kejahatan;

e. memiliki pengetahuan dan pengalaman di bidang perlindungan konsumen;

f. berusia sekurang-kurangnya 30 (tiga puluh) tahun.

g. Anggota sebagaimana dimaksud pada ayat (2) terdiri atas unsur pemerintah, unsur konsumen, dan unsur pelaku usaha.

3. Anggota setiap unsur sebagaimana dimaksud pada ayat (3) berjumlah sedikit-dikitnya 3 (tiga) orang, dan sebanyak-banyaknya 5 (lima) orang.

4. Pengangkatan dan pemberhentian anggota badan penyelesaian sengketa konsumen ditetapkan oleh Menteri.

Pengaturan pada pasal 49 ayat 1 UUPK menyebutkan bahwa Pemerintah di tingkat kabupaten diwajibkan untuk membentuk BPSK. Sedangkan di ayat 3 disebutkan bahwa keanggotaan BPSK terdiri dari unsur pemerintah, unsur konsumen, dan unsur pelaku usaha.

Oleh karena unsur BPSK yang melibatkan pihak di luar pemerintah maka "Badan" di maksud bisa di kategorikan sebagai "Badan" yang bersifat Independen sehingga tidak wajib tunduk pada pengaturan pada UndangUndang Pemerintahan Daerah khususnya Pasal 209 jo Pasal 212 UU 23/2014, dengan demikian tanpa menunggu adanya Perda khusus mengenai BPSK seharusnya sudah bisa di bentuk "Badan" dimaksud dengan berlandaskan pada pengaturan:

- Undang-undang No. 8 tahun 1999 tentang Perlindungan Konsumen pasal 49

- Keputusan Menteri Perindustrian dan Perdagangan Nomor 301/MPP/ Kep/10/2001 tentang Pengangkatan dan Pemberhentian Anggota dan Sekretariat Badan Penyelesaian Sengketa Konsumen

- Surat Keputusan Menteri Perindustrian dan Perdagangan Nomor. 350/MPP/ Kep/12/2001 tentang Pelaksanaan Tugas dan Wewenang Badan Penyelesaian Sengketa Konsumen

- Keputusan Menteri Perindustraian dan Perdagangan Nomor 419/MPP/ Kep/4/2001 tentang Pembentukan Tim 
Penyeleksi Penetapan Anggota Badan

Penyelesaian Sengketa Konsumen

Kedua pendapat tersebut di atas memang sama-sama membawa konsekuensi yang berbeda, yang mana bila tidak memperdebatkan adanya peraturan daerah maka BPSK bisa segera di wujudkan di Madura. Akan tetapi bila menjadikan BPSK sebagai bagian dari "Badan" yang dimaksud dalam Undang-Undang Pemerintahan Daerah maka harus di atur terlebih dahulu dengan payung hukumnya yaitu Peraturan Daerah.

Menurut hemat kami agar tidak menimbulkan polemik di kemudian hari lebih baik di buatkan aturan khusus terkait pendirian BPSK di daerah ini, hal yang sangat sensitif dalam hal ini adalah terkait dengan penganggaran. Apalagi beberapa BPSK sebelumnya yang sudah berdiri pelaksanaannya dibebankan pada APBN dan APBD, dan pengesahan pendiriannya dengan payung hukum anatara lain dalam bentuk Keputusan Presiden Nomor 90 Tahun 2001 tentang Pembentukan Badan Penyelesaian Konsumen Pada Pemerintah Kota Medan, Kota Palembang, Kota Jakarta Pusat, Kota Jakarta Barat, Kota Bandung, Kota Semarang, Kota Yogyakarta, Kota Surabaya, Kota Malang,dan Kota Makassar. Pasal 3 pada Keppres ini mengatur "Biaya pelaksanaan tugas BPSK dibebankan kepada Anggaran Pendapatan Belanja Negara dan Anggaran Pendapatan Belanja Daerah". Kemudian dikuatkan lagi dengan Keputusan Menteri Pedagangan dan Industri Nomor: 605/MPP/
Kep/8/2002 Tentang Pengangkatan Anggota BPSK pada Pemerintah Kota Makassar, Kota Palembang, Kota Surabaya, Kota Bandung, Kota Semarang, Kota Yogyakarta dan Kota Medan. Pada diktum ketiga diatur:

Kepada anggota Badan Penyelesaian Sengketa Konsumen sebagaimana dimaksud dalam Diktum PERTAMA diberikan Honorarium setiap bulan terhitung sejak tanggal pelantikan dengan ketentuan sebagai berikut:

a. Pembayaran Honorarium terhitung sejak pelantikan sampai dengan akhir DesemberTahun Anggaran 2002 dibebankan kepada DIP Proyek Pemberdayaan Perlindungan Konsumen Tahun Anggaran 2002 (Mata Anggaran 01.5203.B.5960) pada Direktorat Perlindungan Konsumen Direktorat Jenderal Perdagangan Dalam Negeri Departemen Perindustrian dan Perdagangan;

b. Pembayaran Honorarium Anggota Badan Penyelesaian Sengketa Konsumen terhitung mulai 1 Januari 2003 dibebankan kepada Anggaran Pendapatan dan Belanja Daerah (APBD) pada masingmasing Pemerintah Kota sebagaimana dimaksud dalam Diktum PERTAMA.

Perkembangannya dengan Keputusan Presiden nomor Keputusan Presiden No. 108 Tahun 2004 Tentang Pembentukan Badan Penyelesaian Sengketa Konsumen (BPSK) dan Keputusan Presiden No. 23 Tahun 2006 Tentang Pembentukan Badan Penyelesaian 
Sengketa Konsumen (BPSK) yang mengesahkan berdirinya BPSK di Kabupaten/ Kota: Pada Tahun 2004 di "Pemerintah Kota Kupang, Kota Samarinda, Kota Sukabumi, Kota Bogor, Kota Kediri, Kota Mataram, Kota Palangkaraya dan pada Kabupaten Kupang, Kabupaten Belitung, Kabupaten Sukabumi, Kabupaten Bulungan, Kabupaten Serang, Kabupaten Ogan Komering Ulu dan Kabupaten Jeneponto, ditambah tahun 2006 di pemerintah Kota Pekalongan, Kota Parepare, Kota Pekanbaru, Kota Denpasar, Kota Batam, Kabupaten Aceh Utara dan Kabupaten Serdang Bedagai.

Kedua Keputusan Presiden tersebut pada diktum ke tiga mengatur Biaya pelaksanaan tugas BPSK dibebankan kepada Anggaran Pendapatan dan Belanja Daerah, hal ini sangat berbeda dengan dua Keppres sebelumnya yang masih memberikan beban terhadap APBN dalam rangka pelaksanaan tugas BPSK. Dengan demikian sudah seharusnya sebelum pembentukan BPSK yang pengesahannya dilakukan oleh Presiden di berikan payung hukum melalui "Peraturan Daerah" hal ini untuk menguatkan institusi ini sendiri, sehingga pada pelaksanaanya yang dibebankan dengan anggaran daerah benarbenar menjadi "Badan" yang keberadaannya menyesuaikan dengan otonomi daerah meskipun hanya bersifat 'small court". Terlebih urusan anggaran yang selama ini menjadi alasan tidak berdirinya BPSK di Madura.

\section{Simpulan}

Konsumen di wilayah Madura juga merupakan bagian dari warga negara di Indonesia yang berhak atas perlakuan yang sama sebagai perwujudan perlindungan terhadap hak asasi manusia berdasarkan Pasal Pasal 28 D butir (1) dan pasal 28 I butir (4) UUD RI Tahun 1945

Kebijakan terkait perlindungan konsumen pasca di undangkannya UUPK nomor 8 Tahun 1999 di wilayah Madura masih terbatas pada usaha yang bersifat preventif yaitu berupa pengawasan melalui operasi pasar oleh dinas terkait dan sosialisasi perlindungan konsumen berbentuk penyuluhan dan brosur menjadi konsumen cerdas.

Model pengaturan hukum yang dapat menjadi dasar bagi pendirian BPSK di Madura dapat diawali dengan membuat "Peraturan Daerah" tentang perlindungan konsumen, hal ini untuk memberikan kepastian hukum bagi keberadaan BPSK terutama berkaitan dengan masalah pendanaan operasional lembaga, selanjutnya baru diusulkan kepada Presiden Republik Indonesia untuk kepentingan pengesahan lembaganya.

Perwujudan perlindungan konsumen sebagai pemenuhan hak asasi manusia di wilayah Madura sudah seharusnya berlandaskan nilai keadilan dan perlindungan bagi masyarakat Madura, oleh karenanya program legislasi daerah perlu merespon urgensi pembentukan BPSK di Madura. 


\section{DAFTAR PUSTAKA}

\section{Buku}

Jimly Asshiddiqie \& M.Ali Safa'at, 2012,

Teori Hans Kelsen Tentang Hukum, Konstitusi Press, Jakarta.

Bambang Sunggono, 2006, Pengantar

Metode Penelitian Hukum, Rajawali, Jakarta.

Zulham, 2013, Hukum Perlindungan

Konsumen, Kencana Prenada Media Group, Jakarta.

\section{Jurnal}

Purwadi, Ari, 2001, Model Penyelesaian Sengketa Konsumen di Indonesia, Jurnal Yustika, Volume 4 No. 2, Media Hukum dan Keadilan, Fakultas Hukum Universitas Surabaya.

Euis Soliha, 1999, Peranan Konsumen, Produsen dan Pemerintah dalam Mewujudkan Perlindungan Konsumen, Volume 31 No. 5, Jurnal Gema Stikubank, Sekolah Tinggi Ilmu Ekonomi Stikubank Semarang.

T.Wulandari, Bernadetta 2006, Badan Penyelesaian Sengketa Konsumen (BPSK)

Sebagai Alternatif Upaya Penegakan

Hak Konsumen di Indonesia, Jurnal Hukum Gloria Juris, Volume 6, No. 2, Fakultas Hukum Universitas Katolik Atma Jaya Jakarta.

\section{Peraturan Perundang-undangan}

Undang-Undang Dasar Republik Indonesia
Undang-undang Nomor 8 Tahun 1999 tentang Perlindungan Konsumen.

Undang-undang Nomor 23 tahun 2014 tentang Pemerintahan Daerah.

Keputusan Menteri Perindustrian dan Perdagangan Nomor 301/MPP/ Kep/10/2001 tentang Pengangkatan dan Pemberhentian Anggota dan Sekretariat Badan Penyelesaian Sengketa Konsumen.

Surat Keputusan Menteri Perindustrian dan Perdagangan Nomor. 350/MPP/ Kep/12/2001 tentang Pelaksanaan Tugas dan Wewenang Badan Penyelesaian Sengketa Konsumen.

Keputusan Menteri Perindustraian dan Perdagangan Nomor 419/MPP/ Kep/4/2001 tentang Pembentukan Tim Penyeleksi Penetapan Anggota Badan Penyelesaian Sengketa Konsumen.

\section{Naskah Internet}

Koran Madura, Kemenag Belum mampu Mendeteksi, http://www.koranmadura. com/kemenag-belum-mampumendeteksi/.

Tesis Hukum, Pengertian, Perlindungan Hukum Menuru Para Ahli, http://tesishukum.com/pengertianperlindungan-hukum-menurut-paraahli/. 